\title{
The Effect of Invisible Intangibles on Volatility of Stock Prices
}

\author{
Omar Alsinglawi ${ }^{1} \&$ Mohammad Aladwan ${ }^{1}$ \\ ${ }^{1}$ Accounting Department, School of Management and Finance, University of Jordan, Aqaba Branch, Jordan. \\ Correspondence: Omar Alsinglawi, Accounting Department, School of Business, University of Jordan, Aqaba \\ Branch, Jordan. E-mail: o.alsinglawi@ju.edu.jo
}

Received: March 18, 2018 Accepted: September 20, 2018 Online Published: October 29, 2018

doi:10.5539/mas.v12n11p290 URL: https://doi.org/10.5539/mas.v12n11p290

\begin{abstract}
The study seeks to investigate the effect of invisible intangible assets on volatility of stock prices as an important indicator of firm value. Valuations of volatility of share prices have become a major challenge for firms; several literature evidences suggests that firm value is not only restricted to physical assets value but also to non-physical assets. The study examines whether invisible intangible assets represented by the amount of costs incurred on research and development, marketing and compensation affects the volatility of stock price. The study relies on secondary data of 59 publicly traded companies in Jordan selected from different economic groups for the period from 2012 to 2016. An OLS regression was run and the results of the entire data set gives significant positive correlation between marketing costs and volatility of stocks; whilst compensation costs was positively negative correlated to stock prices and finally the costs of research and development did not prove any effect on volatility of stock prices.
\end{abstract}

Keywords: invisible intangible assets, IAS 38, volatility, stock prices, Jordan

\section{Introduction}

Value of entity was always regarded as important sign for wealth of investor's. Hence, this value is crucial element for investors and needs to be improved and maximized constantly. For this reason, it is necessary to search, understand and enhance the factors that the value of entity is derived of. Their always an agreement by market participants that firm value is reflected in its stock market price (Tsutomu et al., 2013). Starting the last quarter of previous century and the beginning of this century many worldwide companies witnessed a great change in their values and have undergone major deviations in their market value due to the increase of intangible assets portion (Ortiz, 2009; Obeidat et al., 2013; Masa'deh et al., 2015; Tarhini et al., 2015). Recently many surveys reported that the assets which physically and financially reflected in the entities balance sheet are calculated less than $20 \%$ of the actual value of the company (Knott et al., 2003). Other conclusions also found significant portion of intangible assets are hidden in the reported expenditures of companies in income statement (Salamudin, 2010).

This increase of non-physical assets and their contribution to market value promoted analysts and researchers for further investigation for this interesting topic of analysis (Kohlbeck and Warfield, 2007). The increased importance of intangible assets with the absence of explicit information about their contribution to earnings and value imply also strong incentive for researchers to provide value-added information for high-intangible entities (Basu \& Waymire, 2008). Knott et al. (2003) suggested that the source of economic value and wealth is no longer restricted to the production of material goods but also for the creation of intangible assets. The increase of information about intangible assets and complexity of these assets caused difficulty to forecast entities earnings. Recent accounting literature reported some concerns about the use of costs such as research and development costs to influence the market value of stocks (Chan et al., 2000). Similarly, considerable investigation was undertaken to study the effects of marketing and advertising expenses on returns; for example pharmaceutical companies spend millions of dollars yearly on costs like advertisement to pursuit greater profits and increase market value (Heiens et al. 2008). Hence, investors are naturally questioned whether if intangible assets are truly created invisibly by such expenditures or not (Basu \& Waymire, 2008).

For many years non-physical assets have been widely regarded as main participant and a great driving force for shareholders wealth. The role of such intangibles has become more and more crucial for entities survival and prosperity. Many of recent literature about the effect of assets on stock prices such as (Chan et al., 2001; 
Hennessy \& Whited, 2007) was restricted only to tangible assets as an important determinant of corporate policies and capital structure. However, less attention has been paid for the influence of intangible assets on stock returns. Through our study three types of invisible intangibles represented by the costs incurred on: marketing and advertising; research and development; compensation and salaries will be tested for their effect on volatility of stock prices. These variables are expected in fact to have a significant and positive impact on stock prices value. There are many observations asserted that the stock market behavior is correlated to such intangibles (Amir et al., 2003; Lev \& Sougiannis, 1999). The increasing importance of intangible assets to investors, analyst and shareholders has increased investment communities for more understanding of how companies can create and manage their intangible assets, and how stock prices are affected by intangible assets (Kohlbeck, 2004).

This study contributes to the literature in several fronts. First, introducing new factors that explain stock price volatility; this study model compromise new type of intangibles particularly those invisible intangibles such as the costs reported in income statement; such variables are expected to provide more explanations about the volatility of stock prices in emerged country such as Jordan. Second, the study focuses on exploring the impact of invisible intangible assets on market value of firms and the reported quality of accounting information. Finally, the paper can provide theoretical support to accounting reform in regard to value relevance for standard setters.

The rest of the study proceeds as follows: In Section 2 lay out the basic assumptions and settings of our model through the literature review. In Section 3 include description of the dynamic process of our model. And in Section 4, we analyze the impact of intangible assets. And the final conclusion comments will be stated in Section 5.

\section{Theoretical Background and Hypotheses Development}

\subsection{Intangible Assets}

According to IASB framework intangible asset is a probable future economic benefit obtained or controlled by a particular entity as a result of past transactions or events (IAS, 39). Some concerns were raised by researchers such as Jenkins \& Upton (2001) whom questioned if intangible assets fall under this definition of assets. According to IAS 38 (intangible assets) expenditure on marketing, advertising, salaries, training, start-up, and research and development are prevented from recognition as intangible assets. Although such expenses or expenditures are paid for the core and essential activities of the entity and might create or increase the market value; nevertheless, the standard prevented any form of capitalization of such costs due to its measurement difficulty. For example, if an entity has a team of skilled staff and may be able to identify incremental staff skills leading to future economic benefits from training and the entity may also expect that the staff will continue to make their skills available to the entity. However, an entity usually has insufficient control over the expected future economic benefits arising from a team of skilled staff and from training for these items to meet the definition of an intangible asset. Management or technical talent is unlikely to meet the definition of an intangible asset, unless it is protected by legal rights to use it and to obtain the future economic benefits expected from it (IAS 38, 2010).

Previous research has also reviewed and discussed intangible assets extensively within the frame work of innovationthat arise from research and development. Generally there was no agreement on the economic nature, meaning and classification of such intangible assets. For simplicity, the only intangible assets that permitted to be disclosed in financial reports are only those assets that are non-physical in nature and can be measured reliably. An example of these assets is; patents, trademarks, copyright, goodwill from business combination and brands. In brief, intangible assets are assets that are used in the operation of the business but that have no physical substance and are noncurrent in nature. As for measurement of intangible assets the International Accounting Standard 38 (IAS 38) stated that the basic valuations of intangible assets are at cost; and the subsequent measurement at fair value. These assets will appear on the balance sheet at their cost and will only be listed if significant costs are incurred in their acquisition (IAS, 38).

Some researchers argued that intangible assets can greatly contribute to market value by improving competitive advantage of organization in market (Ittner, 2008). While the value creation process of traditional entities was primarily relied on physical assets and traditional value creation factors (property, raw materials, production facilities and labor), the new value addition perspective of modern entities was achieved by the combination of both traditional physical assets and intangible assets such as innovations, knowledge, information and communication technologies, and the quality of human capital (Arato \& Yamada, 2012; Lev, 2001; Teece, 1998; Spender \& Grant, 1996). Because of this an essential amendment has occurred in the assets structure for entities that take in consideration the value of intangible assts. Although entities works to ward this new perspective of 
value some types of intangible assets cannot be presented or reported in any form of regular financial statements due to the difficulty of measurement in monetary values such as human capital, knowledge, market name and image in market (Penman, 2009; McAdams \& Hawk, 1992).

\subsection{The Nature of and Classification of Intangibles}

It has not been possible yet to combine the different views of scholars to arrive for one definition of intangibles (Grojer, 2001; Kaufmann \& Schneider, 2004). As a result of the lack of this definition intangibles continued to be categorized in different ways (Stewart, 1997; Edvinsson \& Malone, 1997; Sveiby, 1997). In accounting literature, items are required been classified for a number of reasons. One of the most advised classification of assets is to be separated for current and non-current assets; this classification has been always helpful for users to calculate and measure elements such as liquidity and solvency. Another type of classification of assets based on the type of measurement method i.e. historical cost is used for non-current assets, fair value for financial items and so on. Walker (2009) concludes that it is difficult to find any stated purpose for classification in many papers that do classify intangibles. However, for management purpose and in order to manage successfully one has to make visible and put labels on different resources; one way to do that is to put them into different categories (Kaufman and Schneider, 2004). Lev (2001) proposed the following classification groups of intangible assets:

1. Innovation and learning-related; such as research and development.

2. Customer-related; such as brands, trademarks, distribution channels and customer lists.

3. Intellectual-related; such as Education, knowledge, training and compensation.

4. Organization-related; such as organizational design, business processes and unique corporate culture.

\subsection{Empirical Studies}

A large and growing body of literature on intangible assets has provided supportive evidence that excluding of intangibles from assets structure creates a serious deficiency in entity value and contradicts with the faithfulness requirement of financial reporting, since entity value is seen to come from more than one source of assets whether intangible or non-intangible (Aboody \& Lev, 1998; Wyatt, 2005; Penman, 2009). The proponents for the inclusion of intangibles stated that, earnings of entities came from both tangible and intangible and these earnings highly affect market value and stock prices. On the other hand, they warned about the level of uncertainty associated with such recognition of intangibles which might lead to managerial errors regarding the amount reported in entity value (Jones, 2011; Ciftci, 2010). Hence, caution is required from the potential of managers to practice moral hazard or earnings management that causes financial misstatement.

In recent years entities in their normal course of business spend a large amount of their money on expenses for research and development $(\mathrm{R} \& \mathrm{D})$, marketing and advertising, personnel compensating; these costs are regarded as the ways for entities to attract customers or to develop and launch new products or services, create new trademarks or attract talented personnel; such costs are expensive when incurred. For instance, Lev (2001) reported that the excess of entities' returns reflect either stock market mispricing, or represent compensation for the extra risk associated with R\&D. A similar follow-up study also carried out by Lev and Sougiannis (1996) and after they conducted a series of tests on intangibles showed that the excess of returns are more likely a consequence of additional risk. On the contrary, other later research observations by (Lev \& Sougiannis, 1999; Penman, 2009) suggested that it's not the absolute levels of R\&D assets that affect the level of earnings. These results are in line with the hypothesis that the market is, to some extent, fixated on earnings and does not fully understand the impact of R\&D accounting on earnings quality.

Much of current research like the conference paper by Chambers et al., 2002, provided some evidence supporting for the effect of $R \& D$ on earnings volatility. This result was consistent with earlier findings of (Chan et al., 2001). Other recent literature continues to highlights the role of technological change from research and development in increasing firm stock price volatility (Campbell et al. 2001; Shiller, 2000; Pastor \&Veronesi, 2005). Additional research focused on the effect of productivity on market value; clearly innovation has already established a positive relationship with entity market value and its R\&D costs in creation of patents and trade name (Abowd, 2005; Griliches et al., 1991; Pakes, 1985; Zhang, 2000; Chauvin \& Hirschey, 1993; Pastor \& Veronesi, 2004).

Based on previous discussion our first hypothesis is:

\section{H1: Firms with high research and development costs have high volatility in their stock prices.}

From management strategic point view, marketing, selling, and advertising expenditures has often been constantly regarded as a sales trigger, and thus, conceptually viewed as a form of investment. The association 
between such type of expenditures and sales has been found by several prior studies. Broadbent (1993) argued that in an ideal world of investment and if efficient market is available, if we increase one extra dollar on advertising or marketing aspects, we would be able to achieve three dollars of extra sales. In the same stream other studies also suggested that advertising and marketing costs have a significant effect on sales by influencing customer's consumption habits, attitudes, loyalty and customer retention (Case \& Shamblin, 1972; Clarke, 1976). Moreover, researchers also found that marketing and advertising have a positive influence on the market value of entity due to the assumed relationship between these costs and the expectations of cash flows (Park \& Stice, 2000). On the contrary other studies reported some concerns and contradictory results for the effect of intangible assets on share prices; goodwill, rights, patents, trademarks, brands, and costs on marketing and advertising exhibit no significant effect on share values (Ely \& Waymire, 1998; Chauvin \& Hirschey, 1993; Hirschey \& Weygandt, 1985).

Although R\&D costs gained the most attention in intangible assets literature Cummins (2005); Miyagawa \& Kim (2008) extended this focus to include advertisement capital besides R\&D, their results on this type of cost proved that sales increase was significantly correlated with such costs. Likewise, Lev \& Radhakrishnan (2005) reported that much of the increase in sales portion is attributed to Administrative and marketing expenditures. Another study undertaken by Hulten \& Hao (2008) on this issue for pharmaceutical companies showed also R\&D capital, organizational administrative and marketing expenditures contributed to the increase in firm value. The relationship between marketing expenditures and firm performance also has been discussed and carefully reviewed in several other studies. Vast amount of research have been carried to figure out whether this relationship exists or not. Tzang et al. (2008) found that the level of advertising expenditures has a significant positive effect on the intangible value of firm, suggesting that advertising expenditures could be so helpful to generate intangible value; the study results did not support a significant relationship between the advertising expenditure level and the stock returns.Furthermore, some researchers also reported negative relationship between marketing expenditures and firm performance, yet others suggest the existence of negative or positive relationship (Jose et al, 1986). Some prior studies reported concerns for the possibility of managers to use these type of costs in order to increase the market value of firms; suggesting that cautious is required against using marketing expenditure to improbably boost market value of company and share prices (Shah \& Akbar, 2008; Chan et al., 2001).

From previous discussion our second hypothesis is:

\section{H2: Firms with high marketing and selling costs have high volatility in their stock prices.}

Recent business theories regarded human capital as an important and vital component could be employed efficiently to maximize shareholders wealth. In modern business it's possible to create unlimited resources by humans because human's capability ant talent to produce goods, provide services, and enhance process is limitless. Hence, in successful entities human capital works along with physical capital to increase a firm's total capital. Research regarded this human capital as one and essential sources of firm competitiveness as well as to its effectiveness (Lambert \& Larcker, 1989). Providing products and delivering services to customers requires from entities to preserve a highly talented, competent staff. And in order to have such qualified staff companies spend a lot of its monetary resources in compensating of this staff. Although such type of costs are not capitalized or recognized but substantially they are considered as invisible assets that possess a great value to company competitive advantage that thus increase value of firm.

Several previous studies investigated the relationship between staff compensation with factors such as profitability, productivity and market value; many of these studies revealed positive significant relationship (Locke et al., 1980; Gerhart \& Milkovich, 1990; Gerhart \& Milkovich, 1992; Sandusky et al., 2005). Others studies found mixed results for the effect payment policies on company value or share prices; some of these studies claimed that the effect of compensating practices vary significantly according to the type of business, units or divisions and to some degree, differ across jobs (Gerhart \& Milkovich, 1995; Heneman \& Schwab, 1979; Mazzucato, 2003; Görzig \& Görnig, 2012).

Payment methods diversify in companies between non-monetary benefits and cash compensation but all of payment methods regarded as investment in human capital. Most of firm use one or more of payment methods; therefore, in order to assess company value in the market, organizations should evaluate the return obtained from such cost musts. Moreover, they should compare total labor costs that paid for human capital as indicator for company growth and market value. Furthermore, companies should compare the amount of human costs that they pay with other organizations the terms of returns, productivity and market value. Payments to personnel are administered differently across organizations; the design of payment policies differs, in terms of how to pay, in 
what amount and to whom we pay. The rules for payment to human resource differ also across situations. Cowherd \& Levine (1992) when examined whether the amount of the payment effects product quality; they reported that low level staff often compare their payments to those at higher level in the organization structure. If lower-level employees feel inequitably treated, they may seek to reduce their effort from adding value to the organization. As a consequence, staff may prefer relatively little risk in their pay by high emphasis on base salary with low emphasis on uncertain bonuses or incentives (Tosi \& Gomez-Mejia, 1989). At the organization level, some evidence suggests that greater emphasis on short-term bonuses and long-term incentives (relative to base pay) is associated with higher subsequent profitability, at least among top and middle level managers (Gerhart \& Milkovich, 1990).

Our final hypothesis related to human capital that is:

H3: Firms with high compensating levels have high volatility in their stock prices.

Collectively, previously discussed studies outline the critical role for incurring costs of research and development, marketing and adverting and human compensation; and there seems to be some evidence in costs role for creation of invisibly intangibles that might influence the valuation of firms and the quality of accounting information. Our study is motivated by the need to expand this research about the issue for providing more clarity of the problem; and our objective is to provide more evidence about the influence of costs in creating invisible intangibles and thus affecting the volatility in stock prices.

\section{Methodology}

\subsection{Sample}

The sample of the study included all publically traded companies in Amman stock exchange that met the criteria for the sample. The sample was restricted only to companies that reported financial information about research and development, marketing costs and compensation costs in their income statement or in annual reports for the years 2012-2016. The numbers of companies included in the sample was 59 companies represent all economic sectors; the total number of observations that collected from years under study was 236 observations.

\subsection{Method}

The study follows a quantitative empirical method of research and uses real financial market data to examine the relationship between the independent and dependent variables of the study. The study used three accounting-based data for intangible assets: R\&D costs (RDC), marketing costs (MSC), and human-compensation costs (HCC) recognized on the firm's income statement or in disclosures of annual report. To examine the effect of firm's intangible assets and volatility of stock prices, we estimate usingthe following regression model:

$$
S V_{i t}=\alpha+\beta 1 R D C_{i t}+\beta 2 M S C_{i t}+\beta 3 H C C_{i t}+E
$$

Where:

$S V_{i t}$ : is the volatility of stock prices. We calculated the price volatility using the difference between previous year and current year.

$\mathrm{RDC}_{\mathrm{it}}$ : research and development costs for company $i$ at year $\mathrm{t}$.

$\mathrm{MSC}_{\text {it: }}$ : marketing and selling costs for company $\mathrm{i}$ at year $\mathrm{t}$.

$\mathrm{HCC}_{\text {it: }}$ human capital costs (compensation costs) for company $\mathrm{i}$ at year $\mathrm{t}$.

Table 1 represents the variables of the study, measurement of variables and expected correlation between the independent variables and dependent variable of the study.

Table 1. Model variables

\begin{tabular}{|c|c|c|c|c|}
\hline Variable & $\begin{array}{l}\text { Variable } \\
\text { notation }\end{array}$ & Type & Variable description & $\begin{array}{l}\text { Estimated } \\
\text { correlation }\end{array}$ \\
\hline stock volatility & SV & Dependent & $\begin{array}{l}\text { (current year stock price minus previous } \\
\text { year) / Previous year. }\end{array}$ & ---- \\
\hline $\begin{array}{l}\text { Research\& } \\
\text { development costs }\end{array}$ & $\mathrm{RDC}$ & Independent & $\begin{array}{l}\text { All Research and development costs deflated } \\
\text { by total income }\end{array}$ & Positive \\
\hline $\begin{array}{l}\text { Marketing, selling \& } \\
\text { advertising costs }\end{array}$ & MSC & Independent & $\begin{array}{l}\text { All marketing, selling and advertising costs } \\
\text { deflated by total income }\end{array}$ & Positive \\
\hline
\end{tabular}


Human capital costs HCC Independent All wages and salaries, training, incentives, positive board of directors remuneration deflated by total income

\section{Findings and Discussion}

\subsection{Descriptive Statistics}

The descriptive statistics of the study's variables are overviewed in Table (2), the average volatility of stock prices was $6.67 \%$, and this change fluctuated between the minimum value of $-19 \%$ and the maximum value of $11.4 \%$. The possible explanation for this low average of stocks volatility can be attributed to the continued effect of the last financial crises that accrued prior the selected period for the study. The period of the financial crises witnessed negative returns and cash flows for almost all Jordanian economic sectors; thus, investors acted more cautiously after these circumstances and reduced the volume of their trading activities in market. The average expenditures on research and development were too low (RDC) was 0.002 of total income; this result indicates that the average of this type of costs was close to maximum value of 0.003 . In general, this result provides evidence that Jordanian companies rarely spend such costs to improve their market image or value. The average expenditures of marketing, advertising and selling costs (MSC) was about $15 \%$ of total income and the maximum amount was about $40 \%$ of total income. These amounts of expenditures reveal the decision makers trust in such costs to increase income and consequently increase the market price of stocks. The results also of descriptive statics show considerably high amount of costs spent on human resources (HCC); the average expenditures on staff compensation was about $18 \%$ of total income with maximum amount of $23 \%$. This amount is considerably meaningful and appreciated in comparison to the other two types of costs.

Table 2. Descriptive Statistics

\begin{tabular}{lcccc}
\hline & Minimum & Maximum & Mean & Std. Dev. \\
\hline SV & -0.19 & 0.114 & 0.066 & 0.028 \\
RDC & 0.001 & 0.003 & 0.002 & 0.013 \\
MSC & 0.09 & 0.40 & 0.1521 & 0.056 \\
HCC & 0.12 & 0.23 & 0.179 & 0.065 \\
\hline
\end{tabular}

$\mathrm{N}=236$

\subsection{Regression Results \& Discussion}

The multiple regressions' results are presented in table (3), it provide supportive evidence for the relevance of the study's model; the results show that the model was fit for the proposed hypothesis. This fitness was significant; the F-test value was 5.186 at $\mathrm{p}=0.05$ level. Therefore, the Adjusted R Square result empirically proves that the independent variables (RDC, MSC, and HCC) explained $40 \%$ of the change in the dependent variable (MVP). This provides evidence for the existence of significant correlation between the independent variables and the dependent variable of the study. Consequently, the study's predetermined hypothesis is accepted. Our results appeared to be in line with the results of (Griliches et al., 1991; Pakes, 1985; Zhang, 2000; Chauvin \& Hirschey, 1993; Pastor \& Veronesi, 2004).

Table 3. Multiple regression results

\begin{tabular}{cccccc}
\hline Model & R & R Square & Adjusted R Square & F & Sig \\
\hline 1 & 0.388 & 0.150 & 0.143 & 5.186 & 0.000 \\
\hline
\end{tabular}

Predictors: RDC, $M S C, H C C$.

Before discussing the independent variables regression results we should mention that; the results in table (4) show that multicollinearly was not found between the independent variables; the variance inflation factor (VIF) for all was below (10) which is a common cut off value according to Hair et al. (2010). With reference to the same table (4); the coefficient results indicates that: the research and development costs (RDC) was insignificantly positively correlated with stock price value $(\mathrm{B}=0.362$; t-value $=0.581 ; P<0.05)$. As previously 
mentioned in descriptive statistics these types of costs were not dependable by Jordanian firms to raise the amount of return. The first hypothesis results appear consistent with the results of (Lev and Sougiannis, 1999; and Penman, 2009). On the other hand the marketing costs (MSC) as expected found significantly positive correlated to stock prices value $(\mathrm{B}=2.620$; $\mathrm{t}$-value $=2.136 ; P<0.05)$; these results are in line with previous literature of (Miyagawa \& Kim, 2008; Lev \& Radhakrishnan, 2005; Hulten \& Hao, 2008). Likewise the results of human capital cost was appeared significantly correlated to stock prices value but surprisingly was found with negative relation with stock prices $(\mathrm{B}=-3.107$; $\mathrm{t}$-value $=-2.575 ; P<0.05)$. this result can be justified that the spending on building human capital resources takes longer time especially the data was gathered after the financial crises effect and Jordanian companies was suffered from negative effects of this crises and almost all cash flows were negative; and this result similar to the conclusions of (Mazzucato, 2003; Görzig \& Görnig, 2012).

Table 4. The regression model coefficients

\begin{tabular}{lccccc}
\hline & $\begin{array}{c}\text { Unstandardized Coefficients } \\
\text { (B) }\end{array}$ & $\begin{array}{c}\text { Standardized } \\
\text { Coefficients } \\
\text { (Beta) }\end{array}$ & t & Sig. & $\begin{array}{c}\text { Collinearity } \\
\text { Statistics } \\
\text { VIF }\end{array}$ \\
\hline Constant & & & 43.196 & 0.000 & --- \\
RDC & 8.084 & 0.126 & 0.581 & 0.564 & 0.335 \\
MSC & 0.362 & 0.373 & 2.136 & 0.000 & 0.517 \\
HCC & 2.620 & -0.514 & -2.575 & 0.000 & 0.395 \\
\hline
\end{tabular}

Dependent variable: SV.

Independent variables: RDC, MSC, HCC.

Taken together, our findings suggest that, despite of our market weakness in comparison to other worldwide markets; the study results revealed that Jordanian companies are highly aware for the fact that expenditures is capable to build invisible intangible assets and these intangibles have the ability to effect the market as we show their effect on the volatility of stock prices. However, these results approves that; although intangibles do not appear clearly in the reports of accounting but still have the ability to influence the market behavior of investors and other users when evaluating the market value of stock price.

\section{Conclusion and Implications of the Study}

This study aimed to provide empirical evidence for the effect of invisible intangible assets namely, research and development costs, marketing, selling and advertising costs and compensation costs on Stock price volatility. The research was applied on Jordanian listed companies in Amman stock exchange for the period from 2012-2016. The results of the study showed that as expected marketing, selling and advertising costs were positively significant correlated with stock price volatility; the result of compensation costs that represent the human capital was unexpectedly found negatively significant correlated with stock price volatility. The research and development costs (TV) was found with no effect on stocks volatility.

In general, the study's findings have provided evidence that the although these types of expenditures are prohibited to be recognized as intangible assets the results proved that such expenditures have the ability to influence market values of stock prices and consequently the behavior of investors and other decision makers is changed reasonably with these costs when evaluation of the market value of stock prices. These results were consistent with several previously conducted researches. However, these findings provide further support for the excellent association that existed between invisible intangible assets and the change in market behavior.

The study results can provide distinguished implications for the practical benefits of the study issue such as:

- Financial statements information provided useful information to investors, and general public that are helpful for evaluating stock prices and making the necessary investment decisions. Incontrast, the absence of such information to investors causes incorrect investment decision.

- Although the focus of decision makers on tangible assets; intangible assets also could be partially or fully incorporated with other types of assets to capture the real value of stock prices.

- Such results about accounting information have the power to enhance the comparability and credibility of accounting information. 
- As the stock prices volatility found strongly associated with accounting information of such invisible intangible assets decision makers should not underestimate any type of financial disclosure that increases the level of transparency when making their decisions.

\subsection{Limitations, Recommendations and Future Research}

The research shows some limitations which, nonetheless, did not affect the results of the study. One limitation is concerned with the lack of information about research and development in regular financial statements or in annual reports or disclosures; further lack was also in accounting information related to compensation methods. The second limitation was linked to the sample of the study; the number of observations was decreased because we excluded many companies that did not provide continuous information over the selected period of the study.

As for recommendations and future research the study's findings suggest several courses of action for investors, market analysts, and academics as following:

1. Investigating the joint effect of recognized and unrecognized invisible intangible assets on stock prices.

2. Future researches on this topic could encapsulate a longer periods as the researchers intend to use panel or pooled data.

\section{References}

Aboody, D., \& Lev, B. (1998). The value relevance of intangibles. Journal of Accounting Research, 36(3), 161-191.

Abowd, J. M., Haltiwanger, J., Jarmin, R., Lane, J., Lengermann, P., McCue, K., McKinney, K., \& Sandusky, K. (2005). The relation among human capital, productivity, and market value measuring capital in the new economy. The University of Chicago Press, Chicago, 153-203.

Amir, E., \& Lev, B., \& Sougiannis, T. (2003). Do financial analysts get intangibles? European Accounting Review, 12(4), 635-660.

Arato, H., \& Yamada, K. (2012). Japan's intangible capital and valuation of corporations in a neoclassical framework. Review of Economic Dynamics, 15(4), 293-312.

Basu, S., \& Waymire, G. (2008). Has the importance of intangibles really grown? and if so, why?. Accounting and Business Research, 38(3), 171-190.

Broadbent, S. (1993). Advertising effects: More than short term. Journal of the Market Research Society, 35(1), 37-49.

Campbell, J. Y., Lettau, M., Malkiel, B. G., \& Yexiao, X. (2001). Have individual stocks become more volatile? An empirical exploration of idiosyncratic risk. Journal of Finance, 56, 1-43.

Case, K. E., \& Shamblin, J. E. (1972). The effects of advertising carry-over. Journal of Advertising Research, $12(3), 37-40$.

Chambers, D., Jennings, R., \& Thompson II, R. B. (2002). Excess returns to R\&D-intensive firms. Review of Accounting Studies, 7, 133-158.

Chan, L. K. C., Lakonishok, J., \& Sougiannis, T. (2000). The stock market valuation of research and development expenditures. Working Paper, University of Illinois at Urbana- Champaign.

Chan, L., Lakonishok, J., \& Sougiannis, T. (2001). The stock market valuation of research and development expenditures. Journal of Finance, 56(6), 2431-2456.

Chauvin, W., \& Hirschey, M. (1993). Advertising, R\&D expenditures and the market value of the firm. Financial Management, 22, 128-140.

Ciftci, M. (2010). Accounting choice and earnings quality: The case of software development. European Accounting Review, 19(3), 429-459.

Clarke, D. G. (1976). Econometric measurement of the duration of advertising effect of sales. Journal of Marketing Research, 13(4), 345-357.

Cowherd, D. M., \& Levine, D. I. (1992). Product quality and pay equity between lower-level employees and top management: An investigation of distributive justice theory. Administrative Science Quarterly, 37, 302-320.

Cummins, J. G. (2005). A new approach to the valuation of intangible capital. In Corrado, C., J. Haltiwanger, \& D. Sichel (Eds), Measuring Capital in the New Economy (pp. 47-72). The University of Chicago Press, Chicago. 
Edvinsson, L., \& Malone, M. S. (1997). Intellectual capital: Realizing your company's true value by finding its hidden roots. Pratkus, New York, NY.

Ely, K., \& Waymire, G. (1998). Intangible assets and stock prices in the pre-SEC era. Journal of Accounting Research, 37(3), 17-44.

Gerhart, B., \& Milkovich, G. T. (1990). Organizational differences in managerial compensation and financial performance. Academy of Management Journal, 33, 663-691.

Gerhart, B., \& Milkovich, G. T. (1992). Employee compensation: Research and practice. In M.D. Dunnette \& L.M. Hough (Eds.), Handbook of Industrial \& Organizational Psychology (2nd Ed), Palo Alto, CA: Consulting Psychologists Press, Inc.

Gerhart, B., Minkoff, H. B. \& Olsen, R. N. (1995). Employee compensation: Theory, practice, and evidence (CAHRS working paper \#95-04). Ithaca, NY: Cornell University, School of Industrial and Labor Relations, Center for Advanced Human Resource Studies.

Görzig, B., \& Görnig, M. (2012). The dispersion in profits rates in Germany: A result of imperfect competition?. Presented at the 32nd General Conference of International Association for Research in Income and Wealth, Boston, USA.

Griliches, Z., Hall, B., \& Pakes, A. (1991). R\&D, patents and market value revisited, is there ad second (technological opportunity) factor? Economics, Innovation and New Technology, 1,183-201.

Grojer, J. E. (2001). Intangibles and accounting classifications in search of a classification strategy. Accounting, Organizations and Society, 26(7/8), 695-713.

Hair, J. F., Black, W. C., Babin, B. J., \& Anderson, R. E. (2010). Multivariate data analysis. Vectors. NJ: Pearson.

Heiens, R., McGrath, L., \& Leach, R. (2008). The impact of intangible assets and expenditures on holding period returns in the pharmaceutical industry. Journal of Medical Marketing: Device, Diagnostic and Pharmaceutical Marketing, 8(2).

Heneman, H. G., \& Schwab, D. P. (1979). Work and rewards theory. In D. Yoder \& H.G.

Hennessy, C., \& Whited, T. M. (2007). How costly is external financing? evidence from a structural estimation. Journal of Finance, 60, 1129-1165.

Hirschey, M., \& Weygandt, J. (1985). Amortization policy for advertising and research and development expenditures. Journal of Accounting Research, 23, 326-335.

Hulten, C. R., \& Hao, X. (2008). What is a company really worth? Intangible capital and the 'market to book value' puzzle. NBER Working Paper No. 14548.

IAS 38 Basis for Conclusion. (1997). Exposure draft 60, intangible assets, international accounting standards committee.

Ittner, C. (2008). Does measuring intangibles for management purposes improve performance? A review of the evidence. Accounting and Business Research, 38(3), 273-274.

Jenkins, E., \& Upton, W. (2001). Internally generated intangible assets: Framing the discussion. Australian Accounting Review, 11(2), 4-11.

Jones, S. (2011). Does the capitalization of intangible assets increase the predictability of corporate failure? Accounting Horizons, 25(1), 41-70.

Jose, M., Nichols, L., \& Stevens, J. L. (1986). Contributions of diversification, promotion, and R\&D to the value of multiproduct firms: A Tobin's Q approach. Financial Management, 15, 33-42.

Kaufmann, L., \& Schneider, Y. (2004). Intangibles: A synthesis of current research. Journal of Intellectual Capital, 5(3), 366-388.

Knott, A. M., Bryce, D. J., \& Posen, H. E. (2003). On the strategic accumulation of intangible assets. Organization Science, 14(2), 192-207.

Kohlbeck, M. (2004). Investor valuations and measuring bank intangible assets. Journal of Accounting, Auditing \& Finance, 19(1), 29-60.

Kohlbeck, M., \& Warfield, T. D. (2007). Unrecorded intangible assets: Abnormal earnings and valuation. Accounting Horizons, 21(1), 23-42. 
Lambert, R. A., \& Larcker, D. F. (1989). Executive compensation, corporate decision-making, and shareholder wealth. In F. Foulkes (Ed.), Executive compensation, Boston: Harvard Business School Press, 287- 309.

Lev, B. (2001). Intangibles: Management, measurement, and reporting. Brookings Institution, Washington, DC.

Lev, B., \& Radhakrishnan, S. (2005). The valuation of organization capital. In Corrado, C., Haltiwanger, J., \& Sichel, D. (Eds), Measuring Capital in the New Economy (pp. 73-99). The University of Chicago Press, Chicago.

Lev, B., \& Sougiannis, T. (1996). The capitalization amortization and value-relevance of R\&D. Journal of Accounting and Economics, 21, 107-138.

Lev, B., \& Sougiannis, T. (1999). Penetrating the book-to-market black box: The R\&D effect. Journal of Business, Finance and Accounting, 26(3-4), 419-449.

Locke, E. A., Feren, D. B., McCaleb, V. M., Shaw, K. N., \& Denny, A. T. (1980). The relative effectiveness of four methods of motivating employee performance. In K.D. Duncan, M.M. Gruenberg, \& D. Wallis (Eds.), Changes in Working Life (pp. 363-388).

Masa'deh, R., Tayeh, M., Al-Jarrah, I., \& Tarhini, A. (2015). Accounting vs. market-based measures of firm performance related to information technology investments. International Review of Social Sciences and Humanities, 9(1), 129-145.

Mazzucato, M. (2003). Risk, variety and volatility: Innovation, growth and stock prices in old and new industries. Journal of Evolutionary Economics, 13(5), 491-512.

McAdams, J. L., \& Hawk, E. J. (1992). Capitalizing on human assets through performance-based rewards. ACA Journal, 1(1), 60-73.

Miyagawa, T., \& Kim, Y. (2008). Measuring organizational capital in Japan: An empirical assessment using firm-level data. Seoul Journal of Economics, 21(1), 171-193.

Obeidat, B., El-Rimawi, S., Maqableh, M., \& Al-Jarrah, I. (2013). Evaluating the profitability of the Islamic banks in Jordan. European Journal of Economics, Finance and Administrative Sciences, 56, 27-36.

Ortiz, M. (2009). Analysis and valuation of intellectual capital according to its context. Journal of Intellectual Capital, 10(3), 451-482.

Pakes, A. (1985). On patents, R\&D, and the stock market rate of return. Journal of Political Economy, 93(2), 390-409.

Park, C. W., \& Stice, E. K. (2000). Forecasting ability and the stock price reaction to forecast revisions. Review of Accounting Studies, 5(3), 259-272.

Pastor, L., \& Veronesi, P. (2004). Was there a Nasdaq bubble in the late 1990's. Journal of Financial Economics, 81(1), 61-100.

Penman, S. (2009). Accounting for intangible assets: There also an income statement. Abacus, 45(3), 358-371.

Salamudin, A. (2010). Intangible assets valuation in the Malaysian capital market. Journal of Intellectual Capital, 11(3), 391-405.

Sandusky, K. (2005). The relation among human capital, productivity, and market value. In Corrado, C., J. Haltiwanger, \& D. Sichel (Eds.), Measuring Capital in the New Economy (pp. 153-203). The University of Chicago Press, Chicago.

Shah, S., \& Akbar, S. (2008). Value relevance of advertising expenditure: A review of the literature. International Journal of Management Reviews, 10(4), 301-325.

Shiller, R. J. (2000). Irrational exuberance. Princeton University Press, Princeton.

Spender, J. C., \& Grant, R. M. (1996). Knowledge and the firm: Overview. Strategic Management Journal, 17 , 5-9.

Stewart, T. A. (1997). Intellectual capital. The New Wealth of Organization, Doubleday, New York, NY.

Sveiby, K. E. (1997). The new organizational wealth: Managing and measuring knowledge-based assets. Barrett-Kohler, San Francisco, CA.

Tarhini, A., Mgbemena, C., \& Trab, M. S. A. (2015). User adoption of online banking in Nigeria: A qualitative study. Journal of Internet Banking and Commerce, 20(3), 1-8. 
Teece, D. J. (1998). Capturing value from knowledge asset, the new economy, markets for know-how, and intangible assets. California Management Review, 40(3), 55-79.

Tosi, H. L., \& Gomez-Mejia, L. R. (1989). The decoupling of CEO pay and performance: An agency theory perspective. Administrative Science Quarterly, 34, 169-189.

Tsutomu, M., Miho, T., \& Kazuma, E. (2013). Does the stock market evaluate intangible assets? An empirical analysis using data of listed firms in Japan. Rieti Discussion Paper Series 13-e-052, 1-40.

Tzang (Jane), HsuSoo, \& Cheong (Shawn) Jang (2008). Advertising expenditure, intangible value and risk: A study of restaurant companies. International Journal of Hospitality Management, 27(2), 259-267.

Walker, R. G. (2009). Discussion of Lev, Radhakrishnan and Zhang. Abacus, 45(3), 299-311.

Wyatt, A. (2005). Accounting recognition of intangible assets: Theory and evidence on economic determinants. The Accounting Review, 80(3), 967-1003.

Zhang, X. (2000). Discussion of "excess returns to R\&D-intensive firms". The Accounting Review, 7(2-3).

\section{Copyrights}

Copyright for this article is retained by the author(s), with first publication rights granted to the journal.

This is an open-access article distributed under the terms and conditions of the Creative Commons Attribution license (http://creativecommons.org/licenses/by/4.0/). 